\title{
ZAKAT FITRAH: MANAGEMENT, TRADITION, AND MEANING OF EIDAL-FITR
}

\author{
Dian Adi Perdana ${ }^{1 *}$, Fatma Tunali ${ }^{2}$ \\ ${ }^{1}$ IAIN Sultan Amai Gorontalo, INDONESIA \\ ${ }^{2}$ IAIN Sultan Amai Gorontalo, INDONESIA \\ *Correspondence: $\square$ dianadiperdana@iaingorontalo.ac.id
}

\begin{abstract}
Zakat as a source of state income, for Muslims zakat is a spiritual bond of mankind. In the current era, discussing zakat which is included in the state's duties means that it is necessary to increase continuity by helping muzakki by establishing institutions to facilitate the process of raising zakat funds, because this requires government assistance in improving the people's economy. The urgency regarding the management of zakat, zakat fitrah with a good administrative system so that the approval and management of zakat can be accounted for, by taking into account the most important aspects of zakat management, goods and can also be in the form of money, zakat distribution media can be through mosques, social foundations, etc. or directly distributed directly individuals, both at the time of zakat payment and zakat payment channels. The essence of zakat fitrah on the importance of Eid is very important for human life. That the meaning is for humans who teach humans to share and give alms, give happiness to the weak and unable, make food for visitors in the form of rice and other foods, ask each other for value one by one.
\end{abstract}

\begin{abstract}
Abstrak
Zakat sebagai sumber pendapatan negara, bagi umat Islam zakat merupakan ikatan spiritual umat manusia. Di era sekarang ini, membahas zakat yang termasuk dalam tugas negara berarti perlu meningkatkan kontinuitas dengan membantu muzakki dengan mendirikan lembaga untuk memperlancar proses penggalangan dana zakat, karena untuk itu diperlukan bantuan pemerintah dalam meningkatkan perekonomian rakyat. Urgensi tentang pengelolaan zakat, zakat fitrah dengan sistem administrasi yang baik agar persetujuan dan pengelolaan zakat dapat dipertanggungjawabkan, dengan memperhatikan aspek terpenting dari pengelolaan zakat, barang dan juga dapat berupa uang, media distribusi zakat bisa melalui masjid, yayasan sosial, dll atau langsung didistribusikan secara perorangan, baik waktu pembayaran zakat maupun saluran pembayaran zakat. Esensi zakat fitrah atas arti penting Idul Fitri begitu penting bagi kehidupan manusia. Bahwa maknanya bagi manusia yang mengajari manusia untuk berbagi dan bersedekah, memberi kebahagiaan bagi yang lemah dan tidak mampu, membuatkan makanan bagi pengunjung berupa nasi dan makanan lainnya, saling meminta nilai satu demi satu.
\end{abstract}

\section{Article History}

Received: 21-06-2020,

Revised: 27-12-2020,

Accepted: $31-12-2020$

Keywords:

Management

Meanings of Eid Al-Fitr

Tradition of Zakat

Zakat Fitrah

\section{A. Introduction}

Zakat is an instrument of social development through the management of public funds, in the form of money and other materials which are then distributed to the wider community. The state has such an important source of income that even its acquisition can exceed the tax, which is sourced from zakat, this zakat is proof of the implementation of humanity that is just civilized in the second 
precept as a way of life of the Indonesian people that emphasizes the principles of fair and civilized humanity in Pancasila. In the pillars of Islam, zakat is the third point that must be implemented by every Muslim in the world, zakat activities are also actions that promote social to fellow human beings without seeing who they are. social community, namely through tithe from raising funds to distribution. Fair because of the distribution of assets through zakat in proportion to the amount of assets owned by muzakki, civilized because in the process of zakat settlement there is the conscience of muzakki who is guided to carry out the obligation to pay zakat without any coercion or intervention from any party.

In shari'ah, the implementation of zakat is pledged and contracted between muzzaki and amil which is an obligation that must be done so that zakat becomes valid according to muzzaki intentions. With the obligation of tithing for Muslims is an effort to strengthen the spiritual bond of mankind in general and fellow Muslims in particular. In terms of, zakat is a process of transferring ownership of goods that are committed from muzakki to mustahiq as a person who is entitled to receive zakat benefits by following the specified conditions. In this case, those who receive zakat, namely mustahiq, are entitled to receive goods that are tithed according to the levels set in Islam which must be issued by the muzakki. As will be explained later by owning. ${ }^{1}$ In Surah At-Taubah verse 11, Allah SWT has said:

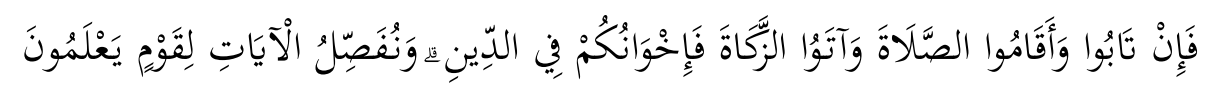

Meaning: "If they repent, establish prayers and perform alms, then (they) are your brothers and sisters of the same religion. And We explain the verses for people who know ".

There is an effort to collect zakat which is included in the duties of the authorities, in this case the government. Thus, the government must continue to act in a continuous manner by assisting the owners of assets or muzzaki either by establishing an institution or foundation to facilitate the process of collecting zakat funds, as this is the government's effort to alleviate poverty and improve the lot of the poor. The existence of a container in the form of a foundation or institution as well as an official program of the government in order to maintain economic stability and religion in the country. In the zakat program as part of community economic development, it has been supported by the existence UU pasal 5 Number 38 Year of 1999. The law supports the existence of zakat according to religious guidance in an effort to improve the welfare of the people and implement social justice by creating usufructuary results with zakat programs.

In this modern era, many Amil Zakat Institutions (LAZ) either in the form of foundations or other legal entities have the role of managing zakat funds from muzzaki to mustahiq in a professional manner. All amil zakat acts to do all matters relating to collection, recording to distribution of zakat assets to mustahiq, which amil is chosen by the community. Amil zakat also functions to build public awareness about the obligations and the law of zakat, as well as the need for socialization to the public that there mustahiq assets that should experience transition from the muzakki, with the collection of zakat is proof as an investment in the afterlife. Zakat is not merely a personal matter of a person but a matter of building the benefit of the people to build the stability of the country's economy both micro and macro scale.

The implementation of zakat fitrah in Indonesia is still mostly done personally by looking for the mustahiq themselves who according to them and distributing zakat to the mustahiq, this is due to the lack of their knowledge of zakat and the presence of institutions or amil-amil zakat in society.

${ }^{1}$ Eka Sakti Habibullah, Implementasi Pengalokasian Zakat pada Ashnaf Fi sabilillah (Yogyakarta: Deepublish, 2015), p: 21. 
Zakat has not been implemented as a tax that functions as a function of poverty alleviation and building the community's economy. Middle Eastern countries have implemented zakat as a source of income which is very influential in the country's development, one example is the existence of regulations regarding the implementation of zakat by the government of Saudi Arabia issued inApril 7, 1951 with number 17/2/28/8634 the contents of which were the stipulation of zakat compulsory system. The Department of Zakat and Zakat Revenue becomes an institution that controls State revenues through zakat revenue sources, in practice a muzzaki (in this case individuals) is allowed to distribute zakat as much as half of their zakat obligations to the department and the rest is channeled directly to mustahiq. ${ }^{2}$

The reality now is that there is a lack of knowledge and intense info sharing, making people only understand zakat as a classical understanding, that is the zakat fitrah which is carried out every Ramadan before the month of Ramadan which is limited to the evening before the month of Shawwal or before the Eid al-FitrAl-Fitr prayer. Yet if we study and understand deeply, zakat is very complex and its types are very many, not only zakat fitrah that we know of. The most frequent and routine zakat is zakat fitrah, the implementation of zakat fitrah is often done at the end of the month of Ramadan, even in the afternoon before entering the month of syawal even seconds before the Eid al-Fitr prayer. This is very sad and often interferes with the performance and time of the amil, who must distribute property (money or non-money) to the mustahiq around their area.

This problem can be a significant threat in interpreting Eid al-Fitr later, even in some regions of Indonesia there are still many amil zakat who work until the last moment and seem urgent. This invites the potential for mismatch of mustahiq, as we know there are 8 asnaf who are entitled to get zakat or as mustahiq, there are: the people whose lives are very miserable life, lack the wealth and energy to meet their needs are called the poor, the people whose lives are still not enough, are very poor in wealth and the below average income is called the Poor, the people responsible for collecting and distributing zakat funds are known as Amil Zakat, an infidel who said the two phrases of shahada as a sign of embracing Islam as a new belief in himself is referred to as a convert to Islam, muslims who are capable and have freed other human beings from slaves to free humans are called People Who Free Slaves, people who have debts for non-immoral interests and are unable to repay are called Gharim, muslims who are fighting for the interests of the moral development of Muslims and the needs of other Muslims (schools, lectures and others) are called Fi Sabilillah people who are not on their way to immorality and experience misery on their journey are called Musafirbilkhos

The fact often happens when pressed in the collection and distribution of zakat, amil is targeting goals to people they do not know even people who are not included in the eight Asnaf. While the provisions on the allocation of utilization and distribution of zakat have been stated in detail in accordance with the word of Allah SWT in Al-Qur'an at Surah At-Taubah verse 60, which means: "Verily, alms-charity is only for the needy, poor people, administrators of zakat, converts who are persuaded by their hearts, to (liberate) slaves, people who are in debt, try in the way of Allah SWT and people who are on their way, as a matter of money, are obliged by Allah SWT. And Allah is All-knowing, All-Wise".

It is obliged for every Muslim to issue the rights of others to fellow Muslims to receive benefits for them with the conditions that have been prescribed. Keep in mind, zakat explained in the Qur'an must be distributed to eight asnaf or mustahiq as a sign of gratitude for the blessings that

${ }^{2}$ Direktorat Pemberdayaan Zakat, Modul Penyuluhan Zakat (Jakarta: Direktorat Jenderal Bimbingan Masyarakat Islam, 2013), p: 26. 
have been given and a servant will increasingly try to get closer to Allah SWT, then to clean themselves and possessions. Zakat in its implementation can create a balance in the ownership of property and distribution of assets so that it is expected to create a prosperous, peaceful and Sentosa community life. Fellow human beings are able to love one another on the basis of ukhuwah Islamiyah and takaful ijtima'i. Community and community development with various facilities such as schools, hospitals, places of worship to other infrastructure facilities is evidence that development can be sourced from zakat $^{3}$

In Ahmad Syafiq's research, according to him there needs to be an effort to foster public awareness in paying zakat, infaq, shodaqoh and waqf (ZISWAF) is a very urgent matter. That is because ZISWAF is one of Islamic philanthropy in realizing general welfare and social justice. Efforts in raising public awareness in carrying out ZISWAF can be done in two ways, there are: firstly is the religious values of the community need to be improved so that with the more religious community will also increase the level of awareness in carrying out ZISWAF and is expected to be more optimal. Secondly is the Government must play a role in increasing the socialization of regulations on ZISWAF, so that the wider community will understand and understand more about what and how to pay for the management of ZISWAF. ${ }^{4}$

There are four schools of jurisprudence that we known, and we also know book Fiqih Islam WaAdillatuhumention the definitions of zakat according to the four schools of thought, there are:

1. According to the Hanafi, the issuance of the right to a portion of the assets owned by the provisions that have been set for certain people who have been determined by religion, and solely because of Allah SWT.

2. According to the Hambali, a matter that is issued at a certain time is a compulsory right and is contained in certain assets to certain groups.

3. According to the Shafi'i, assets issued by a certain party with a contract on an object or item that is issued.

4. According to the Maliki, the existence of partly released goods with the provision has reached its nishab to the person who is entitled to receive it, if ownership is complete in an even number of years in addition to mining goods, plants and found assets. ${ }^{5}$.

In a study by Irsad Andriyanto explained the many benefits in the empowerment of zakat to improve the welfare of humanity that zakat must be included in the list of government work programs and implemented into a government economic policy. Zakat is believed to be able to minimize the problem of poverty if it is managed by a professional or trustworthy philanthropic institution or organization as amil. Public awareness and confidence in paying zakat through amil zakat institutions or organizations have increased from time to time. This needs to be utilized in order to realize the potential of zakat and even ZISWAF, which amounts to 3.4 percent of GDP. In a certain period of time, the government is able to get people's lives out of poverty by distributing zakat optimally and running it well. Therefore, a comprehensive policy design is needed. There are four steps that need to be carried out to ground zakat in the community, there are:

1. Understanding the concept of zakat needs to be socialized as a form of public education. Zakat which is understood as a whole will be the basic key to open the community's willingness to fulfill zakat according to shari'ah.

2. Strengthening government regulations as a form of support for zakat. Given that there will

\footnotetext{
${ }^{3}$ Fuadi, Zakat dalam Sistem Hukum Pemerintahan Aceh (Deepublish, 2016), p: 257.

4 Ahmad Syafiq, "Peningkatan Kesadaran Masyarakat Dalam Menunaikan Zakat, Infaq, Sedekah Dan Wakaf (ZISWAF)," ZISWAF : Jurnal Zakat dan Wakaf 5, no. 02 (2018): p:326-385.

${ }^{5}$ Wahbah Az-Zuhaili, Fiqih Islam Wa Adillatuhu (Jakarta: Gema Insani, 2010), p: 121.
} 
be a significant impact from the implementation of these government regulations.

3. Accelerating the ability of zakat, infaq, shodaqoh and waqf institutions in the country to manage zakat, this is the key to implementing zakat in Indonesia.

4. Establishing international cooperation needs to be strengthened as zakat development as a source of state revenue. ${ }^{6}$

In the KBBI, zakat fitrah in language means zakat which must be given by every Muslim once a year on Eid al- Fitr in the form of daily staples such as rice, corn, wheat and others according to region. ${ }^{7}$ Whereas in Zakat fitrah in the Al-Munawwir Dictionary comes from fi'ilmadhifrom the wordfatarawhich has the meaning of making, making, holding and can also be interpreted iftar and breakfast or breakfast. ${ }^{8}$ We can also interpret by opening or revealing, clean and holy, origin of events, sacred circumstances and return to origin, instincts owned by humans who acknowledge that God Almighty is Allah SWT the creator of nature. ${ }^{9}$

Some functions of zakat fitrah for every human life are worship functions with the effort to get closer to the creator and the function of amaliyah by cleaning oneself fasting from useless words and deeds and providing sufficiency in the needs of poor people while celebrating Eid alFitral-Fitr ${ }^{10}$ Zakat issued by a Muslim from part of his possessions to people who need to purify themselves and their souls and cover the deficiencies that are found in fasting for a month such as dirty words and useless actions are Zakat fitrah in terms. ${ }^{11}$

Required for Muslims who have excess food for one day one night as much as one $s h a^{\prime}$ which is equal to 3.5 liters of food ingredients for the size of Indonesia for food with family, this is a provision of zakat. Islam requires all Muslims, both free and slave, male and female, large and small, rich and poor. The stipulation is that a man is paying the zakat fitrah for him self and that is responsibility. A wife makes the payment of zakat fitrah for herself or by her husband. By law, zakat fitrah has been ordered in the Qur'an and Hadith. In the Qur'an Surah Al-A'la verse 14, Allah SWT has said, yang it means "Surely the one who is cleaning himself (with faith)".

The law of zakat fitrah is obligatory for every Muslim who has fulfilled the terms and conditions of issuing zakat, as the word of Allah SWT in surah Al-Bayyinah verse 5 :

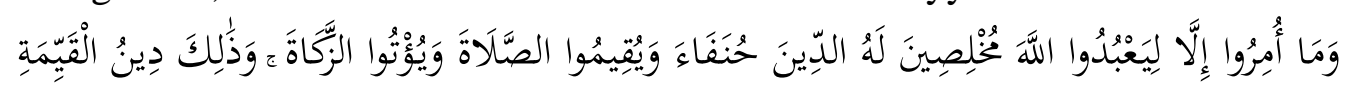

Meaning: "Though they are not told except to worship Allah SWT by purifying obedience to Him in (carrying out) a righteous religion, and so that they establish prayers and perform alms, and that is the right religion".

There is a saying of the Prophet Muhammad SAW which is narrated by Muslims which means "Islam is built on five cases namely testifying that there is no god but Allah SWT and Muhammad SAW is His messenger, establishing prayers, carrying out fasting (in Ramadan), performing zakat and going on pilgrimage to Baitullah".

\footnotetext{
${ }^{6}$ Irsyad Andriyanto, "Pemberdayaan Zakat Dalam Meningkatkan Kesejahteraan Umat," ZISWAF : Jurnal Zakat Dan Wakaf 1, no. 2 (August 16, 2016): p: 227-248, https://doi.org/10.21043/ziswaf.v1i2.1485.

${ }^{7}$ Kamus besar bahasa Indonesia Pusat Bahasa (Gramedia Pustaka Utama, 2008), p: 1017.

${ }^{8}$ Ahmad Warson Munawwir and Muhammad Fairuz, Al Munawwir: kamus Indonesia-Arab (Surabaya: Pustaka Progressif, 2007), p: 1063.

${ }^{9}$ Rian Hidayat El-Bantany, Kamus pengetahuan Islam lengkap: mencakup semua bidang ilmu, Cetakan pertama (Sukmajaya, Depok: Mutiara Allamah Utama, 2014), p: 142.

${ }_{10}$ Abuddin Nata, Pendidikan dalam Perspektif Al-Qur'an (Jakarta: Prenada Media, 2016), p: 78.

${ }^{11}$ Brian Kettell, Case Studies in Islamic Banking and Finance: Case Questions \& Answers, Wiley Finance (West Sussex, UK: Wiley, 2011), p: 82.
} 
With the description of the problem above, the researcher will focus on the discussion there is How to address the tradition of payment and distribution of zakat fitrah to mustahiq at the end of Ramadan; How is the essence of the distribution of zakat fitrah on the meaning of Eid al-Fitr.

\section{B. Method}

This research is a literature review that is relevant to the problems obtained by researchers. Literature review is used to develop concepts or evidence as a basis for studies in research. ${ }^{12}$ This type of research used in this study is library research, namely research conducted through collecting data or scientific papers that aim at the object of research or collection of data that are library, or study carried out to solve a problem which is basically based on a critical and in-depth study of relevant library materials. Before doing library research, the researcher must know in advance what the scientific information will be obtained from. ${ }^{13}$

The nature of this research is descriptive research which focuses on the systematic explanation of facts obtained when the research is conducted. Researchers used the primary data collection method in the form of holy verses of the Qur'an and Hadith as well as secondary data obtained from reliable sources namely books, journals and other sources as supporting data in order to be able to answer social problems, and be synchronized with existing social facts related to zakat fitrah which is carried out during the month of Ramadan. Based on the zakat fitrah problems experienced with the management and traditions of Indonesia, then makes the researcher gather data as research material to enrich the insight of readers and the public. The limitation of the object of this research lies in the social and religious studies taught by Islam to its adherents by using 4 popular schools of fiqh.

After the entire data is collected, the researcher conducts a data analysis technique by analyzing the data so that a conclusion is drawn. To get the right and right results in analyzing data, the author uses content analysis techniques and discussion is taken meaning and essence of the opinions of the scholars regarding zakat fitrah from management to tradition. The strategic steps in content analysis research are the determination of the design of the research model, the search for primary data or primary data, and the search for contextual knowledge. ${ }^{14}$

\section{Discussion}

\section{Management of Zakat Fitrah}

We need to know that zakat fitrah contains two important dimensions in human life, namely the vertical dimension (the relationship between man and Allah SWT) and the horizontal dimension (the relationship between humans and fellow living creatures). In a horizontal line, humans must continue to study and study the importance of zakat, given that zakat has great potential in the welfare of the people and contains humanism values, but the fact is the management of zakat is not so optimal. Vertically, Allah SWT has ordered humans to be fulfilled and it is final or taufiqy, nonnegotiable. Whereas horizontally, the management of zakat is to be channeled to the rightful people who are called mustahiq, the opportunity is open for ijtihady. This is a manifestation of humanism in the Islamic religion that puts forward mutual cooperation and mutual assistance between human beings, so we are taught to practice religion with rahmatanlil 'alamin or Islam as a religion that carries and spreads the values of compassion. ${ }^{15}$

\footnotetext{
${ }^{12}$ V. Wiranata Sujarweni, Metode Penelitian (Yogyakarta: Pustaka Baru Press, 2014), p: 57.

${ }^{13}$ Anwar Sanusi, Metodologi Penelitian Bisnis (Jakarta: Salemba, 2106), p: 32.

${ }^{14}$ Afifudin, Metodologi Penelitian Kualitatif (Bandung: Pustaka Setia, 2012), p: 165-168.

${ }^{15}$ Sony Santoso \& Rinto Agustino, Zakat Sebagai Ketahanan Nasional (Yogyakarta: Deepublish, 2018), p: 1-4.
} 
The largest archipelago in the world such as Indonesia in which there is diversity of ethnicity, race and religion. Indonesia island became the largest Muslim country in the world. Based on this, the potential for zakat is so great and so fantastic. Moreover, Indonesia already has a legal umbrella in terms of zakat management by experiencing the development of laws from time to time to make it easier for the state and the community to manage zakat.Published the Law on Management of Zakat by Decree of the Minister of Religion (KMA) by number23 year of 2011, Law on number 581 year of 1999 and Technical Guidelines for the Management of Zakat by number D year of 2000 in the form of a Decree of the Director General of Community Guidance and Hajj Affairs. Based on the legal basis above, it has been determined that the zakat management organization consists of the Amil Zakat Institution (LAZ) formed by the government from the central, provincial, district / city to sub-district level.

Legal efforts and support for the understanding and application and management of zakat on Muslim communities in Indonesia can be seen in the existence of the laws mentioned above. The management of zakat distribution implemented in Indonesia has two categories, there are:

1. Consumptive distribution,

2. Productive distribution.

A number of assets that must be fulfilled by every Muslim, baligh, understanding and every person whose livelihood is borne by him with certain conditions is called zakat fitrah. A Muslim is obliged to pay Zakat Fitrah since the sun sets at the end of the month of Ramadan or when the Eid al-Fitr Al-Fitr night enters. ${ }^{16}$ In its development, several zakat distribution methods have arisen which need to be studied scientifically and now many productive zakat methods have been applied by various amil zakat institutions. Zakat given to mustahiq as capital to run an economic activity in the form of this business is called productive zakat. Zakat fitrah may not be distributed directly in the form of cash or daily staples such as rice, corn, wheat or other basic needs, so it is better to be collected and managed by amil zakat institutions so that trust and professionalism in the management of zakat is manifested properly. It needs to be ascertained with a nominal value that is not too large, certainly causing the use of zakat funds given to the public or mustahiq can only be used in the short term.

The optimal operation of zakat fitrah will certainly grow the values of welfare and equality that can be felt and enjoyed by every human being. Management of zakat needs to pay attention to good and neat administration, with a good administration and administration system, it will show that the collection of zakat funds and utilization of zakat funds can be justified. ${ }^{17}$ This condition is very beneficial for all human beings with racial, ethnic and religious backgrounds, because the noble values of religion contained in zakat fitrah certainly require the welfare of mankind even though the problem of the rich and poor have become the destiny of a human life in the world. Therefore, the existence of institutions and bodies of amil zakat which operate in various cities and regions and try to ground zakat, greatly help the difficulties of the poor with various programs, including the empowerment program for the poor on the streets. Various programs are implemented with funding from zakat. ${ }^{18}$

16 Muji Astuti, "Peran Psak 109 Dalam Peningkatan Akuntabilitas Dan Transparansi Pelaporan Zakat Di Indonesia,” Jurnal Akuntansi Bisnis 10, no. 1 (January 16, 2018): p: 32, https://doi.org/10.30813/jab.v10i1.986.

${ }^{17}$ Clarashinta Canggih, Khusnul Fikriyah, and Ach Yasin, "Potensi Dan Realisasi Dana Zakat Indonesia," AlUqud : Journal of Islamic Economics 1, no. 1 (January 30, 2017): p: 15-16, https://doi.org/10.26740/al-uqud.v1n1.p1426.

${ }^{18}$ Imamul Muttaqin, "Hukum Produktifitas Zakat Fitrah," TAQNIN: Jurnal Syariah Dan Hukum 1, no. 1 (June 28, 2019): p: 73-74, https://doi.org/10.30821/taqnin.v1i1.4883. 
Uzaifah defines that there are some muzakki behaviors in Indonesia in paying zakat fitrah based on the following indicators:

1. How to calculate zakat fitrah, which is $2.5 \%$ after reaching the Nisab or $2.5 \%$ after perfect assets owned for one whole year, regardless of the amount of assets required to be paid. Zakat searches and professions are paid $2.5 \%$ of net income or gross income.

2. Zakat can be distributed in the form of goods (rice, corn, wheat or other staples) and can also be in the form of money as a form of payment of zakat.

3. Distribution of zakat can be through various media namely mosques, social foundations, religious scholars, amil zakat, or directly distributed to mustahiq.

4. Zakat fitrah is paid once a year in the month of Ramadan.

5. Flow of payment and collection of zakat can be through institutions or institutions.

\section{Tradition of Zakat Fitrah}

Zakat is an obligation ordered by Allah SWT to all Muslims in the world who have advantages and abilities in terms of material possessions to be distributed to people who need social assistance in accordance with the provisions set out in the Qur'an and hadith. Behind the command of zakat especially zakat fitrah actually contains social and spiritual dimensions for the development of lahiriah and batiniyah which are very extraordinary for all elements of society, but in general the community has not been able to implement social humanitarian messages and spiritual messages contained in the obligation of zakat.

The moral message in zakat fitrah is a combination of humanity and divinity which can maximize the values of worship between the servant and Allah SWT, but in this modern era Zakat Fitrah seems to be limited to the fulfillment of obligations. Zakat is a form of social care for the economically weak so that they can meet their needs and at the same time can connect the gap between rich people and poor people. Thus, there will be no distance or gap between the two that triggers social unrest, because poor people feel part of the family of rich people around him.

Historically, Allah SWT has committed its implementation in the second year of Hijriyah precisely in the month of Sya'ban. Since then, the zakat fitrah has become an obligatory expenditure for every Muslim who has an excess of wealth from the family's reasonable needs on the night before and during the Eid al-Fitr al-Fitr, as a sign of gratitude to Allah SWT for the favor of carrying out and completing the fasting month of Ramadan. In addition to providing happiness to the poor people on Eid al-Fitr al-Fitr, it is also intended to purify human sins while performing fasting all day in the month of Ramadan, so that humans really return to the state of physical and mental nature as when they were born from their mother's womb. ${ }^{19} \mathrm{~A}$ baby who is still in the womb has not been exposed to the obligatory zakat. However, if there is a baby born before sunset on the last day of Ramadan, then the zakat fitrah must be fulfilled. Likewise, if a Muslim dies after sunset on the last day of Ramadan, then his zakat must be fulfilled.

Zakat fitrah at the present time, is often only limited to aborting obligations without the intention of sincerity and sincerity which are part of the obligations of Muslims who have been embodied in the third pillar of Islam. Zakat fitrah is often carried out at the end of the month of Ramadan even during the seconds of entering id prayer. The lack of information provided to the public in the form of muroja'ah in religious studies, a warning at the completion of the prayer services and in the form of a reminder between one individual with another individual. With this, it is very important to create a group of management (amil) of zakat that is continuous, if necessary,

${ }^{19}$ Ahmad Hadi Yasin, Buku Panduan Zakat (Jakarta: Dompet Dhuafa, 2012), p: 46. 
an institution or foundation that facilitates the collection and distribution of zakat funds from muzakki to mustahiq. These activities are often carried out so as to give a negative impression both to muzakki, from mustahiq and negative views from the wider community. The habit of collecting and payment of zakat fitrah at the end of time can eliminate the meaning of fitrah which will be achieved by every Muslim when meeting Eid al-Fitr al-Fitr with marked id prayer. Prof. M Quraish Shihab explained about fitrah, according to him fitrah is a system that is manifested by Allah SWT on every creature on this earth. Fitrah especially for all humanity that is what has been created by Allah SWT to his servants, which is related to the human body, mind and spirit. ${ }^{20}$

Zakat fitrah has become a tradition and culture before Eid al-Fitr al-Fitr in Indonesia. This tradition has created the mindset of the local community that zakat only occurs in the month of Ramadan, even the majority of the public thinks that zakat fitrah can be paid later at the end of the month of Ramadan. This kind of community behavior can disrupt the mechanism of the management and distribution of zakat fitrah so that it often becomes less effective and efficient in providing happiness solutions from poverty to mustahiq. As written by Ahmad Hadi Yasin in his book that the time is obligatory to pay zakat fitrah on time namely when the sun sets on the eve of the Eid al-Fitr al-Fitr, but there is no prohibition on paying zakat fitrah before that time, as long as within Ramadan. ${ }^{21}$

Someone issued zakat fitrah means that their possessions have reached the prescribed narration and is not included in the 8 Asnaf which aims to cleanse themselves, their souls and all their assets. The purpose of cleansing the soul and self here is to cleanse from diseases of the heart such as takabur and hunks (miser), as well as giving the rights of others contained in the assets they have. Mustahiq who receives zakat will benefit physically and mentally in the form of fulfilling his wealth and Allah SWT cleanses the feelings of envy and envy to others who are diseases of the human heart. Because of this, zakat as a noble means of raising the standard of living of people, especially the needy by obtaining the rights of those whom Allah has entrusted to others.

Zakat fitrah which is issued at will by muzakki, will have an impact on the validity of the zakat fitrah of a person. If there is a change of time to go forward or backward, that already has a limit. In principle, the payment of zakat fitrah is divided into five times, there are:

1. Jawazul Waqti, in language means allowed time, i.e. the time allowed to issue zakat fitrah since the start or entry of the month of Ramadan.

2. Wajibul Waqti, in language means mandatory time, namely the time when the issuance of zakat fitrah for anyone who has not paid zakat fitrah, the time at sunset on the last day of Ramadan.

3. Afdalul Waqti, in language means the main time, namely the time before heading to the Eid al-Fitr al-Fitr prayer.

4. Makruh Waqti, in language means makruh time, is the time after the Eid al-Fitr al-Fitr prayer, except for udzur such as waiting for relatives or mustahiq.

5. Haromul Waqti, in language means unclean time, which is the day after the Eid al-Fitr holiday. ${ }^{22}$

In the distribution of zakat payment times above, there is a makruh time explaining zakat payment after the Eid al-Fitr al-Fitr prayer (except udzur), the udzur referred to in this matter was like there were no assets (for zakat) or there were no people who were entitled to receive zakat,

\footnotetext{
${ }^{20}$ Achjar Chalil, Pembelajaran Berbasis Fitrah (PT Balai Pustaka (Persero), 2009), p: 4.

${ }^{21}$ Hadi Yasin, Buku Panduan Zakat, p: 48.

${ }^{22}$ Syekkh Abu Bakar Usman bin Sayyid Muhammad Syatha Ad Dimyathi, Hasyiyah I'anah Ath-Thalibin, Juz 2 (Beirut: Dar al-Kutub al-Ilmiyah, 2017), p: 174.
} 
obligatory to be qadha to pay zakat fitrah as soon as possible because of his sinful deeds. So when ending paying zakat because the factor is not found people who meet the category as mustahiq, or zakat property is not within someone's grasp, may end the payment until the person who has the right to receive zakat or assets has been found within someone's grasp. Zakat fitrah is paid before the preacher preaches, if it is paid afterwards it must be for a logical reason and it is tolerated until the setting sun of Eid al-Fitr. If it is issued after that, then zakat is not considered fitrah but alms.

\section{The Essence of Zakat Fitrah on The Meaning of Eid Al-Fitr}

Zakat fitrah which is a mahdhah or pure worship is an activity whose levels have been regulated in time and level by Allah and Rasulullah SAW. Zakat fitrah with the amount of two and a half kilograms of staple food is already boring for those who have excess food or can afford that will be very meaningful for those who need it. The provisions of zakat fitrah generally apply, so it is not possible to add because it will burden some people. On the other hand, there is no obstacle for anyone who will give more help to mustahiq. Obligation of zakat fitrah has a philosophy of human life that is becoming tangible to Muslims in their willingness to provide life for those in need.

According to Culture Emha Ainun Najib, Eid al-Fitr can be interpreted in depth by looking at a substantial and philosophical, that feasting is easy enough to hold activities and be attended by many families or communities, however, it is difficult to fit because it is not only lahiriah who is in a state of fitrah but ruhaniyah is also necessary and obliged as a start we face day after day after carrying out the fasting month of the month as a facilitator of cleaning the human soul. Humans are invited to carry out activities of spiritualization or dematerialization that make Muslims closer to their Lord and after the process is achieved, then one can be said to be fitrah.

According to Prof. Quraish Shihab, fitrah has three meanings, namely the nature of the truth that produces scientific values, nature to the good that produces ethical values and nature to the beauty that produces artistic values. From these three meanings, human life will become whole, peaceful and orderly. Zakat Fitrah is issued approaching Eid al-Fitr al-Fitr with the aim of making beggars or people in need not wander around begging on Eid al-Fitr day. According to the MadzhabSyafi' $i$ of thought, it is obligatory for two reasons, namely the month of Ramadan and Eid al-Fitr, so if one of the reasons has existed, then since then the zakat fitrah may be issued. According to the Madzhab Maliki and Hanafi, if given three days before Eid al-Fitr, it is feared the purpose of giving zakat is not achieved.

The meaning of fitrah found on Eid al-Fitr al-Fitr has the essence of not just wearing new items, especially clothing or clothing which has become a tradition in Indonesia. The new clothes are merely visible symbols and can be recognized as a new innovation from the human body to bring back the progress and intuition of piety as His servant. Rasulullah SAW once said to his friends, the Eid al-Fitr al-Fitr was not marked by a beautiful new piece of clothing, but how can someone be able to maintain and even increase the values of faith and devotion in a servant to Allah SWT by carrying out everything that has been ordered and away from everything that has been forbidden by Him.

The meaning of Eid al-Fitr is very sacred, of course it must be maintained, there are blessings in it which are the result of the continuation of the month of Rajab, month of Syaban to Ramadan. This sacred day is the culmination of our kindness that must be maintained as well and enhanced by the form of Sunnah worship as a companion of our obligatory Amaliyah worship as His servants. Do not let the mindset of aji while always envelop the human mind, because it will be able to damage the practices and meaning of Eid al-Fitr itself. This abundant blessing becomes the most important meaning for every human being. 
Another important amaliyah meaning of Eid al-Fitr is keeping nature with halal bihalal traditions that have become ingrained throughout the archipelago. Actually halal bihalal is an implementation of many of the words of Allah SWT in the Qur'an which emphasizes that the righteous are those who are able to forgive other siblings and also apologize for all their previous mistakes. Because according to Islamic teachings, both the vertical relationship to Allah or hablumminallah as well as the horizontal relationship to fellow human beings or hablumminannas need to be maintained and maintained properly, this is a human attitude to interact with each other between Muslims and other religious communities.

The essence of zakat fitrah is so great for human life in interpreting Eid al-Fitr as a big Muslim holiday. Humans share the use of staple foods and offer hope by filling hunger and thirst with disadvantaged brothers. This has meaning for humans by teaching humans to share and give love, giving happiness to those who are weak and unable, making a fortune for traders of rice and other staple foods, teaches the value of morality that one goodness is rewarded by one goodness also and draws a servant closer to Allah SWT.Yusuf Al-Qardhawi quoted Al-Kasani's theory, zakat has several important meanings ${ }^{23}$, there are:

1) Paying zakat is an effort of fellow human beings to help the weaker people, help people who are more in need of help and support their weak lives to be able to carry out their obligations to Allah SWT in terms of the value of monotheism, preparing infrastructure to carry out obligations is also a human obligation.

2) Paying zakat can cleanse humans of various sins that have been committed and refine human character so that they can be generous and forgiving, which in reality humans tend to be stingy.

3) Abundance of grace, blessings and gifts that Allah SWT has given to people who have excess assets in meeting their basic needs, which incidentally they are happy and happy in life in the world. Meanwhile, grateful for all the favors that have been given is a human obligation, both in a sense or aqliyah or the law of Allah SWT or shari'ah. In general there are three rights contained in the obligation to pay zakat, there are:

a.The rights of the poor needy

b.The rights of the general public

c. The rights of Allah SWT

Zakat Fitrah certainly cannot be separated from the meanings of fitrah that will be achieved by all Muslims in the world by marking the arrival of the evening of Shawwal or Eid al-Fitr al-Fitr night which in the morning all Muslims will perform their id prayers. This fitrah process is the peak of prosperity and happiness for every Muslim after following a month of fasting and worshiping with various temptations and obstacles in it. The fasting journey undertaken is an effort of all human beings in finding their true self and returning to their nature and also returning to their true life.

\section{Conclusion}

Zakat is one of the sources of state income, with the obligation of tithing for Muslims is as an effort to strengthen the spiritual ties of mankind in general and fellow Muslims in particular. In this modern era, the collection of zakat which is included in the duties of the authorities means the government must continue to act continuously to help the muzzaki either by establishing an institution or a foundation to facilitate the process of collecting zakat funds, because this is the

\footnotetext{
${ }^{23}$ Agustino, Zakat Sebagai Ketahanan Nasional, p: 9.
} 
government's effort to reduce poverty and improve the lot of the poor. The establishment of an institution is an official program of the government in order to maintain domestic economic and religious stability. The reality that often occurs is the lack of knowledge and intense info sharing that makes people only understand zakat as a classical understanding, namely the zakat fitrah which is carried out every Ramadan, whereas if we study and understand in depth, zakat is very complex and its types are very many, not only zakat fitrah and this is very sad about the ignorance of the community towards zakat.

The urgency of zakat management especially zakat fitrah is to optimize the administration system and administration which is maximally aimed at making the collection and distribution of zakat funds and utilization of zakat funds accountable by the manager or amil zakat, by paying attention to the most important aspects in the management of zakat, there are :

1. How to calculate zakat fitrah, which is $2.5 \%$ after reaching the Nisab or $2.5 \%$ after perfect assets owned for one whole year, regardless of the amount of assets required to be paid. Zakat searches and professions are paid $2.5 \%$ of net income or gross income.

2. Zakat can be distributed in the form of goods (rice, corn, wheat or other staples) and can also be in the form of money as a form of payment of zakat.

3. Distribution of zakat can be through various media namely mosques, social foundations, religious scholars, amil zakat, or directly distributed to mustahiq.

4. Zakat fitrah is paid once a year in the month of Ramadan.

5. Flow of payment and collection of zakat can be through institutions or institutions.

The process of interpreting Eid al-Fitr that is so sacred must certainly be maintained and there is a blessing in it which is the culmination of our goodness which must be maintained as welland enhanced by the form of Sunnah worship as a companion Amaliyah worship obliged us as His servants. The meaning of Amaliyah Eid is not merely to clean oneself but to maintain the fitrah with halal bihalal traditions that have become ingrained throughout the archipelago which emphasizes that the righteous are those who are able to forgive their other siblings and also apologize for their past mistakes. Because humans must maintain habumminAllah and hablumminannaas and maintain habummina'alam.This is a human attitude to interact with each other between Muslims and other religious communities. The essence of zakat fitrah on the meaning of Eid al-Fitr is so great for human life that it has meaning for humans by teaching humans to share and give love, giving happiness to those who are weak and unable, making a fortune for traders of rice and other staple foods, teaches the value of morality that one goodness is rewarded by one goodness also and draws oneself closer to Allah SWT.

\section{E. Bibiliography}

Ad Dimyathi, Syekkh Abu Bakar Usman bin Sayyid Muhammad Syatha. Hasyiyah I'anah AthThalibin. Juz 2. Beirut: Dar al-Kutub al-Ilmiyah, 2017.

Afifudin. Metodologi Penelitian Kualitatif. Bandung: Pustaka Setia, 2012.

Agustino, Sony Santoso \& Rinto. Zakat Sebagai Ketahanan Nasional. Yogyakarta: Deepublish, 2018.

Andriyanto, Irsyad. "Pemberdayaan Zakat Dalam Meningkatkan Kesejahteraan Umat." ZISWAF : Jurnal Zakat Dan Wakaf 1, no. 2 (August 16, 2016): 1-22. https://doi.org/10.21043/ziswaf.v1i2.1485.

Astuti, Muji. "Peran Psak 109 Dalam Peningkatan Akuntabilitas Dan Transparansi Pelaporan Zakat Di Indonesia." Jurnal Akuntansi Bisnis 10, no. 1 (January 16, 2018). https://doi.org/10.30813/jab.v10i1.986. 
Az-Zuhaili, Wahbah. Fiqih Islam Wa Adillatuhu. Jakarta: Gema Insani, 2010.

Canggih, Clarashinta, Khusnul Fikriyah, and Ach Yasin. "Potensi Dan Realisasi Dana Zakat Indonesia." Al-Uqud: Journal of Islamic Economics 1, no. 1 (January 30, 2017): 14-26. https://doi.org/10.26740/al-uqud.v1n1.p14-26.

Chalil, Achjar. Pembelajaran Berbasis Fitrah. PT Balai Pustaka (Persero), 2009.

Direktorat Pemberdayaan Zakat. Modul Penyuluhan Zakat. Jakarta: Direktorat Jenderal Bimbingan Masyarakat Islam, 2013.

El-Bantany, Rian Hidayat. Kamus pengetahuan Islam lengkap: mencakup semua bidang ilmu. Cetakan pertama. Sukmajaya, Depok: Mutiara Allamah Utama, 2014.

Fuadi. Zakat dalam Sistem Hukum Pemerintahan Aceh. Deepublish, 2016.

Habibullah, Eka Sakti. Implementasi Pengalokasian Zakat pada Ashnaf Fi sabilillah. Yogyakarta: Deepublish, 2015.

Hadi Yasin, Ahmad. Buku Panduan Zakat. Jakarta: Dompet Dhuafa, 2012.

Kamus besar bahasa Indonesia Pusat Bahasa. Gramedia Pustaka Utama, 2008.

Kettell, Brian. Case Studies in Islamic Banking and Finance: Case Questions \& Answers. Wiley Finance. West Sussex, UK: Wiley, 2011.

Munawwir, Ahmad Warson and Muhammad Fairuz. Al Munawwir: kamus Indonesia-Arab. Surabaya: Pustaka Progressif, 2007.

Muttaqin, Imamul. "Hukum Produktifitas Zakat Fitrah.” TAQNIN: Jurnal Syariah Dan Hukum 1, no. 1 (June 28, 2019). https://doi.org/10.30821/taqnin.v1i1.4883.

Nata, Abuddin. Pendidikan dalam Perspektif Al-Qur'an. Jakarta: Prenada Media, 2016.

Sanusi, Anwar. Metodologi Penelitian Bisnis. Jakarta: Salemba, 2106.

Sujarweni, V. Wiranata. Metode Penelitian. Yogyakarta: Pustaka Baru Press, 2014.

Syafiq, Ahmad. "Peningkatan Kesadaran Masyarakat Dalam Menunaikan Zakat, Infaq, Sedekah Dan Wakaf (ZISWAF).” ZISWAF : Jurnal Zakat dan Wakaf 5, no. 02 (2018). 